\title{
Zmanjševanje odpora in čusłvenih blokad pri pisanju
}

\author{
Majda Cencič
}

\begin{abstract}
Problem pisanja je že dolgo prisoten v našem vsakdanjem življenju. Bojimo se pisanja in napišemo le najnujnejše, kar moramo. Če je mogoče, uporabimo namesto zapisane besede drugo sredstvo za sporočanje. Toda v življenju brez pisanja kljub temu ne gre.
\end{abstract}

Tudi »informacijska družba« zahteva komuniciranje prek pisnega jezika, tako da smo pogosto prisiljeni komunicirati tudi prek zapisane besede, hkrati pa smo tudi odvisni od pisne komunikacije drugih. To zahteva od nas spretnosti pisanja in branja primerno informacijskim pisnim besedilom, ko je vsebina informacij bolj pomembna kot pa tehnična pravilnost zapisa.

Poglejmo, kaj vključuje pisanje in katere ovire so v nas samih, da imamo odpor do pisanja. Zavedamo se, da potrebujejo naši pismeni izdelki izboljšave, a smo pogosto negotovi, kako bi naše pisne spretnosti in sposobnosti lahko izboljšali.

Pisno sporočanje se v šoli v glavnem usmerja na spis (izdelek ali produkt pisanja), zanemarja pa se pisec besedila in proces pisanje, ki privede do besedila. Proučevanje pisanja naj zato ne bi obšlo procesa pisanja, ker lahko že sam proces nakazuje rezultat. Velja pa tudi obratno: »Če se želi izboljšati pismeno besedilo, se mora izboljšati proces. « (Simard 1985, str. 101) Vse to pa mora biti prilagojeno piscu in njegovi spoznavni (kognitivni) shemi, ker pisec ugradi v svoj spoznavni sistem le tisto, kar tudi sprejme (dojame). Drugo se lahko nauči, ne more pa uporabiti, ker ni povezano in vključeno v njegovo spoznavno strukturo.

\section{Pisanje kol proces}

V strokovni literaturi je težko zaslediti eno samo opredelitev pisanja, saj ga različni avtorji različno opredeljujejo glede na to, $s$ katerega vidika proučujejo problem pisanja.

Pisanje se kot zapleten in medsebojno povezan proces lahko proučuje iz različnih vidikov, in sicer: kot del procesa sporočanja (komunikacije), kot spoznavni (kognitivni) proces, kot individualni proces, kot družbeni proces, kot ustvarjalni proces, $\mathrm{z}$ jezikovnega vidika, $\mathrm{z}$ družbenega vidika, v odnosu do govora, v odnosu do branja itn.

Pisanje prikazuje Toporišič (1994, str. 173-174) v obliki modela, ki ga sestavljajo tvorec besedila, naslovnik in samo besedilo. Vsako sporočanje pa poteka v določenih okoliščinah (prostorskih, časovnih...), ki bolj ali manj vplivajo na besedilo. »Stvarnost se $\mathrm{v}$ besedilo predstavlja le prek tvorčeve zavesti (in podzavesti), ubesedeno pa naslovnik $z$ druge strani spet zagleda le prek svoje zavesti (in podzavesti).« (Toporišič 1994, str. 173)

Družbena razmerja, ki tvorijo okoliščine sporočanja se kažejo, ko se pisec prilagaja naslovniku, zato piše drugače staršem, znan$\mathrm{cu}$, učitelju, tujcu ali drugim. Lahko bi dodali, da se v prilagajanju naslovniku izraža »odgovornost « pisca. Podobno odgovornost prilagajanja mora imeti tudi bralec, da razume pisca (povz. po Vähäpassi 1986, str. 16).
Zadravec-Peščeva (1994, str. 63) z vidika pragmatičnega jezikoslovja opredeljuje sporočanje (govorno ali pisno) kot dejavnost sporočevalca, ki je motivirana in usmerjena $\mathrm{k}$ ciljem.* $\gg$ Uresničuje se $\mathrm{v}$ odvisnosti od sporočevalčevega odnosa do dejanskosti in naslovnika.« (Zadravec-Pešec 1994, str. 63)

Navedena opredelitev poudarja poleg dejanske situacije in naslovnika tudi motivacijski vidik in cilje pri sporočevalcu piscu. Tako motivacija kot cilji so lahko zunanji ali notranji. Raziskave (npr. Daly in Miller 1975, Faigley, Daly in Witte 1981, povz. po Scardamalia in Bereiter 1985, str. 780) ugotavljajo, da je uspešnost pisanja močno odvisna od »pisne bojazni«, anksioznosti do pisanja, ki vpliva na to, kako dobro ljudje pišejo in kako se počutijo pri pisanju.

Pisanje kot komunikacijsko dejavnost med tvorcem in naslovnikom zamegljuje posebnost pisanja, ki je v tem, da je pisanje tudi samokomunikacija, kar pomeni po komunikacijski teoriji, da je avtor sporočila (sporočevalec ali tvorec) hkrati tudi naslovnik svojega sporočila. Pisanje je samokomunikacija, če ima pisec namen samemu sebi izraziti (»zliti na papir«) ali razjasniti občutke ali čustva, to pomeni, če ga usmerjajo notranji cilji.

Hkrati pa pisec tvori neko besedilo brez takojšnje povratne informacije, sodelovanja ali posredovanja bralca. Ta monologni vidik pisanja je ena najpomembnejših značilnosti, ki ločijo pisanje od interakcije »na štiri oči «.

Pisec se trudi in poskuša pisati jasno, zanimivo, primerno, razumljivo itn., medtem ko je bralčeva naloga branje besedila in njegova interpretacija glede na domnevni namen pisca. Med piscem in bralcem je $\mathrm{z}$ vidika dejanja pisne komunikacije medpredmetna razdalja (intersubjective distance), zaradi katere se pisec ne more $\mathrm{z}$ bralcem povezati neposredno, ampak samo prek besedila (povz. po Vähäpassi 1986, str. 15). Kar pomeni, da je besedilo posrednik ali vezni člen med piscem in bralcem ter enakovredni del pisnega sporočanja.

Kljub temu ne smemo zanemariti spoznavne (kognitivne) strukture pisca, ki je vir sporočila in glavni dejavnik v procesu sporočanja.

Pisanje je s spoznavnega (kognitivnega) vidika zapleten in prepleten proces, ki ga bistveno ne moremo ločevati od splošnega mišljenja in učenja (povz. po Vähäpassi 1986, str. 19). Kot kognitivni proces vključuje in poudarja dejavnost pisca, ki je sposoben predstaviti in/ali reflektirati tako zunanje opazovanje kot notranjo izkušnjo.

Kognitivni psihologi razlagajo, da pismene naloge aktivirajo različne osebne sheme, ki so v dolgotrajnem spominu pisca. Te

\footnotetext{
* Razumevanje pa opredeljuje kot dejavnost naslovnika.
} 
abstraktne strukture iz dolgotrajnega spomina nato služijo razvoju informacij na podoben način, kot se oblikujejo pojmi (Rumelhart in Ortony 1977, povz. po Vähäpassi 1986, str. 20).

Po spoznavni (kognitivni) teoriji je pisanje opredeljeno kot proces oblikovanja informacij, ki jih piše nek dejavni subjekt, ki uporablja znanje, s katerim razpolaga po osebnih načrtih, shemah in strategijah. Spoznavni (kognitivni) pristop pisanja pa označuje še:

- predstavo pisca kot vira in oblikovalca informacij,

- spoznavno (kognitivno) dejavnost, ki se izraža prek načrtovanja in se udejanji $\mathrm{v}$ postopku, podobnem reševanju nekega problema,

- sposobnost posameznika, da nadzira pisanje,

- poudarjanje spomina kot skladišča spoznanj o pojmih, postopkih (povz. po Boscolo 1990, str. 4).

Kognitivnih modelov pisanja je kar nekaj. Hayes in Flowerjeva (1983, str. 208-210) sta leta 1980 prvič predstavila spoznavni (kognitivni) model procesa pisanja. V skladu z njunim procesom so vsaj trije osnovni deli procesa pisanja: načrtovanje, samo pisanje in pregledovanje.

Po Hayesu in Flowerjevi (1983, str. 210) oseba, ki piše, ne samo vključuje cilje $\mathrm{z}$ oblikovanjem mreže podpornih ciljev, ampak včasih tudi oblikuje nove cilje. Okoliščine, v katerih se oblikujejo novi cilji, nas spominjajo na pojav »inkubacije«. Novi cilji so odvisni od intenzivnosti priprave, to pomeni tudi od znanja, ki ga je pisec »nabral« v kakem prejšnjem »napornem « pisanju, ki se izkaže kot dobrodošlo, toda nepričakovano, ko se pisec sreča z drugačnimi cilji. To pomeni, da čeprav je pisanje ciljno usmerjena dejavnost, ni nujno, da pisanje usmerjajo le tisti cilji, $\mathrm{s}$ katerimi je pisec začel pisati. Pomemben vidik piščeve ustvarjalnosti je sposobnost oblikovanja novih ciljev med samim pisanjem.

Beaugrande (1984, povz. po Scardamalia in Bereiter 1985, str. 781-783) je podal večstopenjski model. Vanj je združil eksperimentalna psihološka odkritja in povezuje različne simbolne strukture, ki delujejo med oblikovanjem besedila. Model je imenoval interakcija vzporednih stopenj (parallel-stage interaction), kar pomeni, da različni simbolni procesi oblikovanja besedila potekajo bolj ali manj samodejno, vzporedno in prepletajoče. Kar se zgodi kot rezultat procesiranja na eni stopnji, lahko spremeni poznavanje tekočega stanja na drugih stopnjah.
Oseba, ki piše, mora imeti širok dostop do različnih mentalnih predstav in navidezno kontrolo struktur za usklajevanje operacij na različnih stopnjah (slika 1.)

Beaugrandov model pisanja poudarja mentalne procese, ki potekajo v spominu, in se s tem navezuje na Hayesov in Flowerov model. Mentalne procese in stopnje, ki potekajo istočasno za nazaj in za naprej, ima bolj natančno navedene. Ker omenja le mentalno raven, ne predstavlja sinteze do procesa pisanja.

Navedeni model in vsi drugi spoznavni (kognitivni) modeli pisanja poudarjajo pisca in njegove miselne procese, ki potekajo med pisanjem. Zanemarjajo pa bralca in odnos ali razmerje pisca do bralca ter okoliščine, $v$ katerih pisanje poteka.

Lahko povzamemo, da je pisanje tako proces sporazumevanja kot tudi spoznavni (kognitivni) proces.

Če gledamo pisanje $\mathrm{z}$ dvojne perspektive kot komunikacijsko in kognitivno dejavnost, je pisanje tako aktiviranje miselnih procesov pisca kot tudi prenašanje (izražanje) sporočila. S tega vidika sta družbena (komunikacijska) in individualna (kognitivna) perspektiva pisne situacije medsebojno povezani.

$\mathrm{V}$ celotnem procesu pisanja pa mora pisec upoštevati in vključiti tudi jezikoslovno (lingvistično) področje, ustrezno funkcijsko zvrst ter upoštevati druga pravila pisnega jezika ter namen ali cilje sporočanja.

Pisanje s teh treh vidikov opredeljuje Vähäpassijeva (1987, str. 7-8) in pravi, da je pisanje večnivojski proces ustvarjalnega mišljenja, s katerim pisec pokaže sposobnost istočasne organizacije različnih vrst spretnosti in sposobnosti. Med pisanjem pisec kognitivne strukture (izkušnje, opazovanja, znanje) opremi $\mathrm{z}$ jezikovnimi izrazi in na osnovi teh struktur oblikuje (kreira) besedilo, ki ga bralec potem razume ali pa tudi ne.

Vähäpassijeva (1987, str. 8-9) je v svoj model (slika 2) združila tri glavne razsežnosti pisnega procesa: spoznavne (kognitivne), komunikacijske in jezikovne.

Spoznavna (kognitivna) dimenzija ima dve razsežnosti: odnos med temo in piscem ter odnos med temo in bralcem. Čim bolj je tema oddaljena od pisca, več kognitivnega napora mora uporabiti pisec; in podobno: čim bolj je tema oddaljena od bralca, več interpretativnega napora mora opraviti bralec. $\mathrm{V}$ tem mentalnem naporu razumevanja teme ali naloge odigrata pomembno vlogo spoznavni (kognitivni) shemi pisca in bralca.

Komunikacijska razsežnost pisanja vključuje posebno vrsto sporočanja - pisno sporočanje, $\mathrm{v}$ katerem sta pisec in bralec $v \gg m e d-$ predmetni« povezavi, saj sta povezana le prek besedila in prek besedila med seboj komunicirata.

$\mathrm{Na}$ besedilo pa ne vpliva samo osebna, kognitivna shema osebe, ki piše, ampak tudi njeno jezikovno področje. S pomočjo tega področja mora pisec preiti od govora do besedila in od pomena do natančnega pisnega izraza $\mathrm{z}$ namenom, da doseže komunikacijske cilje in tvori ustrezno vrsto besedila.

Slika tudi nakazuje, da mora biti vsaj nekaj prekrivanja tako med kognitivno shemo pisca in bralca kot tudi med jezikovnim področjem pisca in bralca. Če je v tej »medpredmetni« povezavi malo skupnega, 


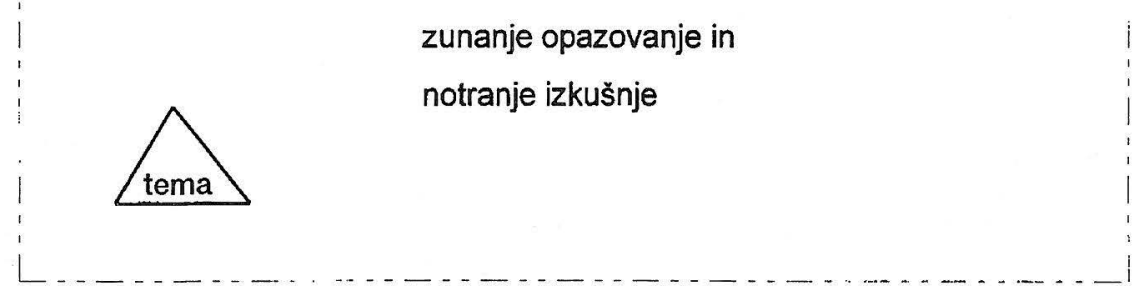

kognitivna shema

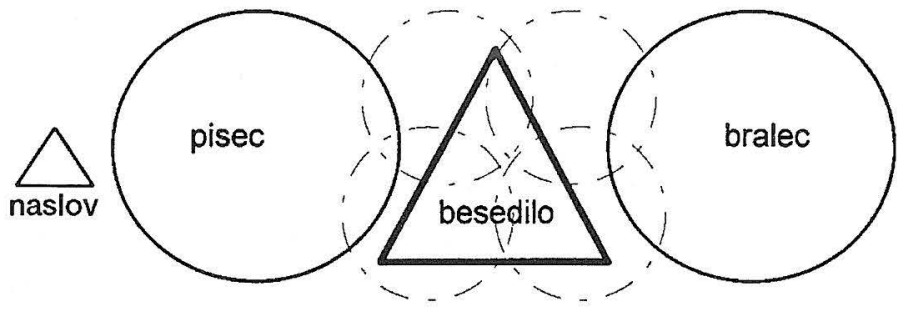

jezikovno področje

dati, da lahko izboljšamo naše pisanje in da lahko pišemo bolj jasna, zanimiva in nasploh bolj učinkovita besedila. Toda začeti moramo pisati in odmisliti predsodek, da smo brez talenta za pisanje.

»Pisanje je neke vrste vaja, ki se jo dela $v$ šoli in ki ima malo skupnega $z$ resničnim življenjem. «

Veliko šolskega pisanja je res namenjenega vaji. Toda tudi tako se razvija mišljenje. Tudi v poslovnem svetu je veliko povsem ustaljenega pisanja, ki mu lahko damo neko »osebno noto

$\gg$ Dobro pisati pomeni pravilno pisati. Če si zapomniš vsa jezikovna pravila in jih znaš uporabiti, znaš dobro pisati.«

Pravila naj pisca usmerjajo pri Slika 2: Dejavniki v procesu pisanja (prir. po Vähäpassi 1987, str. 8).

mora pisec uporabiti več komunikacijskih spretnosti in napora, da vzpostavi ali obdrži povezavo z bralcem.

Celovito opredeljuje pisanje tudi Cooper (1975, str. 113), ko razmišlja o pisanju kot o kompleksnem osebnem in družbenem dogodku. Pravi, da je pisanje hkratno razmišljanje in ubesedovanje, ki temelji na prejšnjih izkušnjah in znanju. Dejanje pisanja je prenos izkušenj in realnega sveta $\mathrm{v}$ pisno obliko. Spodbuda - dražljaj za pisanje lahko pride od pisca samega ali od drugih. Če pride spodbuda od učitelja ali nekoga nadrejenega, bo pisanje pod vplivom piščevega odnosa (interakcije) do učitelja (nadrejenega) in sošolcev (ali sodelavcev).

Učenčevo pisanje odseva tako stopnjo njegovega spoznavnega (kognitivnega) razvoja kot tudi učenčev jezikovni razvoj, včasih pa tudi njegov moralni razvoj, socialni občutek, znanje itn.

Kot smo videli v prejšnjem modelu, manjka tudi v tem »integracijskem« modelu vključitev motivacije. Motivacija je pomemben vidik pisnega procesa in jo najdemo v različnih stopnjah piščeve dejavnosti ter poudarja pomembnosti določene stvari $\mathrm{v}$ določenem času in v določenem osebnem življenju.

Pri pisanju pa ima pomembno vlogo tako področje motivacije kot tudi področje čustev in s tem v zvezi »čustvene blokade« (povz. po Scardamalia in Bereiter 1985, str. 780) ali zavore v procesu pisanja. Razni piščevi predsodki, tabuji ali miti ovirajo pisanje. Simard (1985) je navedel nekaj takih ovir, ki so lahko »usidrane« v piscu. Preglejmo nekatere izmed njih.

\section{Zavore v procesu pisanja}

»Veliko ljudi misli, da je pisanje talent in da se nekateri z njim rodijo, drugi pa ne. Pravijo, da je pisanje podobno igranju nekega inštrumenta in da ljudje, ki so brez talenta, ne bodo nikoli dobro igrali ali dobro pisali.«

Simard (1985, str. 101) priznava, da imajo nekateri ljudje talent za pisanje. Hkrati pa dodaja, da če pogledamo delo dobrih pisateljev, vidimo, da predvsem dobro razmišljajo. Sami sebi si postavljajo vprašanja o tem, kaj resnično želijo povedati, komu želijo povedati in kakšen učinek želijo doseči pri bralcih. Med samim pisanjem pa se sprašujejo, ali so dosegli zastavljene cilje ali ne.

Glede na to, da smo tudi mi občasno pisci, se moramo zave- pisanju, ne pa da ga ovirajo. Če se preveč razmišlja o pravilnosti zapisa, bo to oviralo ustvarjalnost in pisec ne bo mogel veliko »spraviti na papir«. Pravila naj bodo le pripomoček, da se oblikuje učinkovito pisanje, ne pa past, v katere se pisec ujame med pisanjem. (Ker je dober pisec tudi dober bralec, je dobro trenirati oči, da zaznajo, kako drugi pisci uporabljajo pisni jezik.)

»Obstaja preveč različnih vrst besedil in stilov pisanja, zato bi morali biti strokovnjaki, da bi bili sposobni vse uporabiti.«

Čeprav je res veliko različnih pristopov do pisanja in vrst besedil, pa naj to ne pomeni ovire pri pisanju. Za dobro pisanje je značilno, da je vedno osebno, stilno drugačno, jasno, informativno... Eno vrsto zapisanega besedila od drugega razlikuje namen, tema in bralci. Ko se soočamo s katerokoli pismeno nalogo, moramo upoštevati, katere informacije želimo posredovati, komu in čemu (misliti moramo na učinek).

»Praktično - poslovno pisanje ni ustvarjalno pisanje. Ker je pisanje, ki se zahteva tako $\mathrm{v}$ šoli kot $\mathrm{v}$ vsakdanjem življenju pogosto konformistično, je uspešno le, če je podobno drugim pismenim izdelkom.«

Zavedati se moramo, da so tako pravila kot različne oblike pismenih besedil le pripomoček, ne pa omejitev. Če to sprejmemo, poskušamo narediti posamezno pismeno besedilo drugačno od drugih podobnih pisnih besedil.

»Vsi priročniki in navodila navajajo, kako pisati, in če jim sledimo, lahko dobro pišemo.«

Kljub temu, da je misel pravilna, nas navadno vodi v posnemanje. Podobna je misel, da nekdo ne zna pisati. Če to misli, ne bo pisal in s tem ne bo razvijal svojega pisanja. Vsak pisec pa mora razvijati in kultivirati svoj sistem pisanja, to pomeni, da je pozoren na skladnjo in stil pisanja. Pri tem se moramo zavedati, da je pisanje proces, ki vključuje (kot smo že navedli) vsaj tri različne stopnje: ustvarjalno načrtovanje, sámo pisanje in pregledovanje (popravljanje).

»Vsak učitelj ali nadrejeni ima svoj način pisanja, ki ga je treba vedno znova spoznati in pozabiti prejšnji način pisanja.«

Za pisce, ki ne razumejo, kaj je pisanje in zakaj je pisanje pomembno, je trditev veljavna, saj ima vsak učitelj ali nadrejeni nekakšne norme, ki jih poskuša upoštevati in ki ga usmerjajo pri vrednotenju pismenega besedila. Toda tujih nasvetov ni dobro avtomatično sprejemati le zato, ker jih izraža za nas neka »avtoriteta«, saj se tudi način poučevanja spreminja. 
»Če nimaš dobrega predznanja iz osnovne šole in srednje šole, si izgubljen.«

Misel pogosto poudarjajo učitelji, tako da jo postopoma prisvojimo in mislimo, da nam primanjkuje znanja, da imajo drugi boljše znanje pisanja kot mi. Ker je pisanje tudi oseben proces, začutimo vsak napad na naše pisanje kot napad na nas same. Zato dokler tako razmišljamo, ne bomo znali dobro - učinkovito pisati, saj nas bodo take in podobne misli ovirale pri pisanju in ustvarjale čustvene blokade.

Če bomo mislili, da slabosti pisanja odražajo slabosti nas samih, ne bomo razvijali naših sposobnosti in spretnosti pisanja, ker si jih ne bomo upali razvijati. Poskušati se moramo »distancirati« od našega pismenega izdelka. Če imamo pomanjkljivosti v zapisih, vemo to bolje kot drugi, zato moramo pošteno vrednotiti naše pisanje in posebej vrednotiti osebno gledanje ali osebni pogled na neko stvar.

Sprejeti moramo dve resnici:

1. le malo ljudi pozna vsa pisna pravila,

2. nobene preproste ali lahke poti ni za razvijanje pisanja, razen prakse - pisanja samega.

Edini magični obrazec za pisanje je želja izboljšati pisanje glede na določene, individualno postavljene cilje.

\section{Sklep}

To je le nekaj predsodkov, ovir, tabujev ali čustvenih blokad, ki so prirejene po Simardu (1985) in jih moramo preseči, da bo naše pisanje učinkovito. Glede na to, da je pisanje zapleten spoznavni proces, proces pisnega sporočanja (komuniciranja), ki se od govornega sporočanja bistveno razlikuje, zahteva od nas več časa, napora, ustvarjalnosti, hkrati pa smo na pismene izdelke tudi bolj občutljivi.

Ker pisanje pogosto manj uporabljamo kot govorno sporočanje, imamo pri njegovi uporabi številne predsodke. Nekatere smo pridobili med šolanjem in so lahko posledica šolske neuspešnosti, druge kasneje. Ti predsodki pa nas zavirajo pri poskušanju, da bi začeli pisati. Če pa začnemo pisati, se hkrati privajamo na pisanje, ga izboljšujemo in razvijamo ali kultiviramo.

Dobro - učinkovito pisanje ni zgolj pravilno pisanje, ampak je pisanje, ki ustreza namenu, bralcem in je dovolj informativno.

Navedene misli naj nam pomagajo preseči prve zapreke, ki nas ovirajo, da začnemo pisati. Čeprav bodo naši prvi zapisi morda okorni, neizdelati, pa se moramo zavedati, da je pisanje proces, ki ga sestavljajo trije osnovni podprocesi: načrtovanje, pisanje in pregledovanje. To pomeni, da se pismeni izdelek ne konča, ko je besedilo na papirju, ampak ga je treba še veliko predelovati, popravljati, dopolnjevati. In čeprav ga bomo dali iz rok preden bo popolnoma dodelan, bomo med pisanjem tudi sami nekaj pridobili in »pridobitev« lahko vključili pri naslednjem pisanju.

mag. Majda Cencič

asistentka na Pedagoški fakulteti v Ljubljani

\section{Lifergfura}

Beaugrande, R. A., Dressler, W. U. (1992). Uvod v besediloslovje. Ljubljana: Park.

Boscolo, P. (ur.) (1990). Insegnare i processi della scrittura nella scuola elementare, Firenze: La Nuova Italia.

Cencič, M. (1995). Tehnike raziskovanja pisanja. Sodobna pedagogika, 1. 46, št. 7-8, str. 362-371.

Cencič, M. (1994). Razvijanje pisnega sporočanja s primernim vrednotenjem. V: Čok, L. (ur.). Učiti drugi/tuji jezik - kje, koga, kako. Ljubljana: Pedagoška fakulteta, str. 223-232.

Cooper, C. (1975). Measuring Growth in Writing. English Journal, vol. 64, št. 3 , str. 111-120.

Dular, J., Korošec, T. (1983). Slovenski jezik 3. Maribor: Založba Obzorja.

Hayes, J. R., Flower, L. S. (1983). Uncovering Cognitive Processes in

Writing: An Introduction to Protocol Analysis. V: Mosenthal, P., Tamor, L., Walmsley, S. (ur.), Research on Writing: Principles and Methods. New York: Longman, str. 207-220.

Hayes, J. R., Flower, L. S. (1980). Identifying the Organization of Writing Processes. V: Gregg, L. W., Steinberg, E. R. (ur.), Cognitive Processes in Writing. Hillsdale: Erlbaum, str. 3-30.

Korošec, T., Dular, J. (1985). Slovenski jezik 4. Maribor: Založba Obzorja.

Scardamalia, M., Bereiter, C. (1985). Research on Written Composition. V: Mittrock, M. (ur.), Handbook of Research on Teaching. 3. izd. New York, London: MacMillan Publishing Company, Collier MacMillan Publishers, str. 778-803.

Simard, R. (1985). Reducing Fear and Resistance by Attacking the Myths. College Teaching, vol. 33, št. 3, str. 101-107.

Toporišič, J. (1994). Slovenski jezik in sporočanje, 1. Maribor: Založba Obzorja.

Vähäpassi, A. (1987). Theoretical and Comparative Approaches to the Domain of School Writing. V: Degenhart, R. E. (ur.), Assesment of Student Writing in an International Context. Jyväskylä: Kasvatustieteidem Tutkimuslaitos, str. 3-24.

Vähäpassi, A. (1986). The Domain of School Writing and the Development of the Writing Tasks. V: Gorman, T. P., Purves, A. C., Degenhart, R. E., The International Writing Tasks and Scoring Scales. The IEA Study of Written Composition, vol. 1, str. 14-43.

Zadravec-Pešec, R. (1994). Pragmatično jezikoslovje: Temeljni pojmi. Ljubljana: Pedagoški inštitut, Center za diskurzivne študije. 